Original Research Paper

\title{
Pengembangan Lembar Kegiatan Mahasiswa Berbasis Eksperimen Pada Materi Pencemaran Lingkungan
}

\author{
Fitriani $^{1^{*}}$ \\ ${ }^{1}$ Program Studi Pendidikan Kimia Universitas Muhammadiyah Pontianak, Indonesia
}

Article history

Received: December $30^{\text {th }} 2019$

Revised: June $26^{\text {th }} 2019$

Accepted: July $10^{\text {th }} 2019$

*Fitriani: Program Studi Pendidikan Kimia Universitas Muhammadiyah Pontianak, Indonesia;

Email: fitriani@unmuhpnk.ac.id

\begin{abstract}
The characteristic of the material of environmental pollution requires the real object from surrounding as learning resources. Hence, it demands the students move in or out of the classroom activity. Therefore, it is required to develop a student's worksheet based on experiments that are expected to explain the theory about nature that can be revealed by experimental activities, especially on the material of environmental pollution. This study was Research and Development from the thiagarajan model of $4 \mathrm{D}$ (Define, Design, Development and Disseminate). However, this study was conducted until the development stage only without the disseminate stage, because this study did not use it for a large scale. The instruments used in this study were validation sheets and respondent questionnaires for student's worksheets based on experiments. The result of this study showed that the validity percentage based on the value of three expert validators with an average of 93,52\% included the very valid category. Meanwhile, the average percentage results of the respondent questionnaire included very applicable category from the first and the second tryouts were $90,98 \%$ and 89,16 $\%$, respectively. In conclusion, student's worksheet based on experiments can be stated as the teaching materials which has been validated and very applicable to be used in the learning process.
\end{abstract}

Keywords: Student's worksheet based on experiments; Environmental pollution; Development

Abstrak: Karakteristik bahan pencemaran lingkungan membutuhkan benda nyata dari sekitarnya sebagai sumber belajar. Oleh karena itu, itu menuntut siswa untuk keluar masuk kegiatan kelas. Oleh karena itu, diperlukan untuk mengembangkan lembar kerja siswa berdasarkan eksperimen yang diharapkan dapat menjelaskan teori tentang alam yang dapat diungkapkan oleh kegiatan eksperimental, terutama pada bahan pencemaran lingkungan. Penelitian ini adalah penelitian dan pengembangan dari model thiagarajan $4 \mathrm{D}$ (Define, Design, Development and Disseminate). Namun, penelitian ini dilakukan sampai tahap Pengembangan hanya tanpa tahap Diseminasi, karena penelitian ini tidak menggunakannya untuk skala besar. Instrumen yang digunakan dalam penelitian ini adalah lembar validasi dan kuesioner responden untuk lembar kerja siswa berdasarkan eksperimen. Hasil penelitian ini menunjukkan bahwa persentase validitas berdasarkan nilai tiga validator ahli dengan rata-rata $93,52 \%$ termasuk kategori sangat valid. Sementara itu, hasil persentase rata-rata dari kuesioner responden termasuk kategori yang sangat berlaku dari uji coba pertama dan kedua masing-masing 90,98\% dan $89,16 \%$. Kesimpulannya, lembar kerja siswa berdasarkan eksperimen dapat dinyatakan sebagai bahan ajar yang telah divalidasi dan sangat berlaku untuk digunakan dalam proses pembelajaran

Kata Kunci: Lembar kerja siswa berdasarkan eksperimen; Pencemaran lingkungan; Pengembangan 


\section{Pendahuluan}

Salah satu mata kuliah yang wajib ditempuh oleh mahasiswa Pendidikan Kimia Universitas Muhammadiyah Pontianak adalah Kimia Lingkungan dengan bobot 2 sks. Kimia Lingkungan merupakan cabang ilmu kimia yang mempelajari tentang interaksi yang melibatkan zat dan reaksi kimia di alam, serta polusi atau pencemaran di alam (Situmorang, 2012). Berdasarkan silabus mata kuliah Kimia Lingkungan, terdapat materi yang berhubungan dengan kehidupan sehari-hari yaitu Pencemaran Lingkungan. Materi tersebut banyak membahas tentang aktivitas manusia dalam kehidupan sehari-hari yang berkaitan dengan teknologi yang digunakan manusia sehingga dengan adanya teknologi yang berkembang akan menimbulkan suatu dampak pada lingkungan sekitar (Palar, 2008).

Perkuliahan Kimia Lingkungan khususnya pada materi Pencemaran Lingkungan masih bersifat teoritis dan menggunakan ceramah sehingga kurang memaksimalkan kemampuan mahasiswa dalam melakukan diskusi dan presentasi. Bahan ajar yang digunakan masih terbatas pada print out dari materi perkuliahan (Power Point) yang dibuat oleh dosen serta hanya sebagian kecil mahasiswa yang aktif mencari informasi bahan ajar melalui internet. Mahasiswa kurang mendapatkan pengalaman langsung yang membuat mahasiswa cenderung monoton menggali materi dan kurang adanya aktivitas mahasiswa yang berkaitan dengan materi Pencemaran Lingkungan. Berbagai cara dapat dilakukan oleh dosen untuk mendukung perkuliahan Kimia Lingkungan. Salah satunya berupa bahan ajar yang dapat membantu dosen dan mahasiswa belajar secara terarah dalam proses perkuliahan adalah dengan menggunakan Lembar Kegiatan Mahasiswa.

Lembar Kegiatan Mahasiswa atau student worksheet adalah lembar-lembar yang berisi tugas yang harus dikerjakan mahasiswa untuk menguasai kompetensi yang dipersyaratkan (Eurika, 2013). Lembar kegiatan (lembar kerja) biasanya berupa petunjuk dan langkah-langkah untuk menyelesaikan suatu tugas. Lembar kegiatan tidak hanya berisikan soal-soal yang menuntut mahasiswa untuk menjawabnya tetapi juga berisi konsep-konsep yang membantu mahasiswa dalam mempelajari materi perkuliahan. Untuk mendapatkan lembar kegiatan yang kaya manfaat dan dapat memperoleh hasil yang optimal, diperlukan persiapan yang matang dalam perencanaan materi (isi) dan tampilan (desain) lembar kegiatan.
Materi lembar kegiatan harus diturunkan dari tujuan instruksional pembelajaran, sedangkan desain dikembangkan untuk memudahkan mahasiswa berinteraksi dengan materi yang diberikan. Karakteristik materi pencemaran lingkungan membutuhkan objek nyata dari lingkungan sekitar sebagai sumber belajar, sehingga materi ini menuntut mahasiswa untuk bergerak aktif di dalam maupun di luar ruangan kelas. Mahasiswa dapat memanfaatkan lingkungan sekitar untuk memahami konsep dan mengetahui jenis pencemaran lingkungan itu sendiri.

Berdasarkan hal tersebut, maka perlu dikembangkan Lembar Kegiatan Mahasiswa yang diharapkan dapat memberikan penjelasan teori terhadap suatu fenomena alam yang dapat diungkapkan atau dibuktikan melalui kegiatan eksperimen. Salah satu cara yang digunakan untuk mengaktifkan mahasiswa dalam proses perkuliahan dan mendapatkan pengalaman atau fenomena langsung melalui kegiatan eksperimen adalah Lembar Kegiatan Mahasiswa berbasis eksperimen. Lembar kegiatan tersebut dirancang khusus untuk materi Pencemaran Lingkungan yang tidak hanya menyajikan wacana secara teoritis tetapi juga disertai dengan kegiatan eksperimen sederhana menggunakan alat dan bahan yang ada di lingkungan sekitar. Kegiatan eksperimen ini bertujuan untuk mengaplikasikan teori dan pembahasan tentang pencemaran udara, air dan tanah melalui percobaan-percobaan sederhana. Sehingga mahasiswa memperoleh pengetahuan teori dengan pengalaman nyata terhadap masalah dan dampak dari pencemaran lingkungan.

Beberapa penelitian pengembangan yang telah dilakukan antara lain Mahardika dan Mastuang (2016) yang menghasilkan Lembar Kegiatan Mahasiswa dan materi ajar topik Teori Kinetik Gas yang dapat melatih penalaran proporsional mahasiswa. Selain itu, penelitian Juniati dan Budayasa (2017) yang menghasilkan bahan ajar geometri fraktal berbasis eksperimen yang dapat meningkatkan kompetensi mahasiswa. Hasil-hasil penelitian tersebut menunjukkan bahwa bahan ajar yang dikembangkan berupa Lembar Kegiatan Mahasiswa telah memenuhi kategori valid, praktis dan efektif, sehingga layak digunakan untuk pembelajaran di perguruan tinggi.

Berdasarkan uraian tersebut, maka peneliti tertarik untuk mengembangkan Lembar Kegiatan Mahasiswa berbasis eksperimen pada materi Pencemaran Lingkungan. Dengan adanya Lembar Kegiatan Mahasiswa, diharapkan pembelajaran akan menjadi lebih menarik, menyenangkan dan interaktif dengan melakukan kegiatan eksperimen. 
Melalui lembar kegiatan, mahasiswa diharapkan dapat belajar secara sistematis dan mendapatkan informasi tentang konsep materi yang dipelajari.

\section{Metode}

Penelitian ini tergolong penelitian pengembangan (Research and Development) dikarenakan penelitian ini menghasilkan produk berupa Lembar Kegiatan Mahasiswa berbasis eksperimen untuk mahasiswa Pendidikan Kimia Universitas Muhammadiyah Pontianak pada semester ganjil tahun akademik 2017/2018. Penelitian pengembangan Lembar Kegiatan Mahasiswa ini menggunakan model pengembangan 4-D (four $D$ model). Peneliti memilih model ini karena setiap tahapannya lebih sistematis, selain itu model ini juga mudah dipahami dan mudah diterapkan dalam proses pengembangan.

Menurut Mulyatiningsih (2014) langkahlangkah dalam membuat Lembar Kegiatan Mahasiswa dengan mengikuti model pengembangan perangkat pembelajaran yang dikembangkan oleh Thiagarajan (1974) terdiri dari 4 tahap pengembangan yaitu tahap pendefinisian (Define), tahap perancangan (Design), tahap pengembangan (Develop), dan tahap penyebaran (Desseminate). Namun pada penelitian ini hanya sampai pada tahap pengembangan karena Lembar Kegiatan Mahasiswa tidak digunakan pada skala yang lebih besar.

Untuk mengetahui tingkat validitas Lembar Kegiatan Mahasiswa berbasis eksperimen digunakan kategori validitas bahan ajar, hal ini dapat dilihat pada Tabel 1.

Tabel 1. Kategori Validitas Bahan Ajar

\begin{tabular}{lll}
\hline No & Angka & Kategori Validitas \\
\hline 1 & $85,2 \%-100 \%$ & $\begin{array}{l}\text { Sangat Valid, atau dapat } \\
\text { digunakan tanpa revisi } \\
\text { Cukup valid, atau dapat } \\
\text { digunakan namun revisi kecil }\end{array}$ \\
3 & $70,1 \%-85 \%$ & $\begin{array}{l}\text { Kurang valid, disarankan tidak } \\
\text { digunakan karena perlu revisi } \\
\text { besar } \\
\text { Tidak valid, atau tidak boleh } \\
\text { digunakan }\end{array}$ \\
4 & $01 \%-50 \%-7 \%$
\end{tabular}

Sumber: Akbar (2013)

Persentase validasi masing-masing validator dihitung dengan menggunakan rumus:

$$
\mathrm{V}=\frac{\mathrm{TSe}}{\mathrm{TSh}} \times 100 \% \quad(\text { Akbar, 2013). }
$$

Keterangan:

$\mathrm{V} \quad=$ Persentase validasi

TSe $\quad=$ Total skor empirik yang diperoleh
TSh = Total skor maksimum yang diharapkan.

Selanjutnya penilaian kelayakan juga penting dilakukan untuk memastikan layak tidaknya bahan ajar tersebut digunakan dalam proses pembelajaran. Persentase kelayakan dihitung dengan menggunakan rumus berikut:

$$
\mathrm{K}=\frac{\mathrm{F}}{\mathrm{N} \times \mathrm{I} \times \mathrm{R}} \times 100 \% \quad \text { (Riduwan, 2009) }
$$

Keterangan:

$\mathrm{K}=$ Persentase kelayakan

$\mathrm{F} \quad=$ Jumlah jawaban respon

$\mathrm{N} \quad=$ Skor tertinggi dalam angket

I = Jumlah pertanyaan dalam angket

$\mathrm{R}=$ Jumlah responden

Untuk mengetahui tingkat kelayakan Lembar Kegiatan Mahasiswa berbasis eksperimen digunakan kategori kelayakan bahan ajar. Kategori interpretasi skor berdasarkan skala Likert dapat dilihat pada Tabel 2.

Tabel 2. Kategori Kelayakan Bahan Ajar

\begin{tabular}{lll}
\hline No & Angka & Kategori Kelayakan \\
\hline 1 & $81 \%-100 \%$ & Sangat Layak \\
2 & $61 \%-80 \%$ & Layak \\
3 & $41 \%-60 \%$ & Cukup Layak \\
4 & $21 \%-40 \%$ & Kurang Layak \\
5 & $05-205$ & Tidak Layak \\
\hline
\end{tabular}

Sumber: Riduwan (2009)

\section{Hasil dan Pembahasan}

\section{Analisis Kevalidan}

Pada penelitian ini, peneliti mengembangkan produk bahan ajar berupa Lembar Kegiatan Mahasiswa Berbasis Eksperimen. Pengembangan Lembar Kegiatan Mahasiswa ini melalui beberapa tahapan yang bertujuan agar diperoleh Lembar Kegiatan Mahasiswa berbasis ekeperimen yang memenuhi kategori kevalidan dan kelayakan sebagai bahan ajar pada mata kuliah Kimia Lingkungan di FKIP Program Studi Pendidikan Kimia Universitas Muhammadiyah Pontianak.

Data yang disajikan berupa ringkasan penelitian hasil validasi, saran dan masukan dari tiga validator yang memiliki kemampuan dan kapabilitas dalam menilai dan memberi saran demi kesempurnaan pengembangan bahan ajar. Selain itu, dilakukan uji coba I dan uji coba II terhadap mahasiswa menggunakan angket respon. Teknik analisis data yang dilakukan adalah analisis deskriptif, yaitu dengan mendeskripsikan persentase hasil validasi dan uji coba produk pengembangan. Persentase hasil validasi dan uji 
coba produk didapatkan dari penjumlahan skor yang diperoleh dari setiap aspek yang dinilai dibagi dengan skor total maksimal. Data hasil validasi terhadap Lembar Kegiatan Mahasiswa berbasis eksperimen adalah berupa penilaian, saran dan masukan untuk perbaikan dan kelayakan produk. Berikut adalah hasil rekapitulasi validasi oleh ketiga validator dapat dilihat pada Tabel 3.

Tabel 3. Hasil Rekapitulasi Validasi oleh Ketiga Validator

\begin{tabular}{lllllc}
\hline No & Validator & Total Skor Empiris & Total Skor Harapan & $\mathrm{V}=\frac{T S e}{T S h} \times 100 \%$ & $\mathrm{~V}=\frac{\mathrm{V} 1+\mathrm{V} 2+\mathrm{V} 3}{3}$ \\
\hline 1 & I & 60 & 72 & $83.33 \%$ & $93,5 \%$ \\
2 & II & 71 & 72 & $98,61 \%$ & $93,5 \%$ \\
3 & III & 71 & 72 & $98,61 \%$ & $93,5 \%$ \\
\hline
\end{tabular}

Tabel 3 menunjukkan bahwa hasil rekapitulasi validasi untuk Lembar Kegiatan Mahasiswa berbasis eksperimen oleh ketiga validator diperoleh sebesar 93,52\%. Artinya produk yang dikembangkan masuk ke dalam kategori sangat valid dan dapat digunakan untuk uji coba di kelas. Namun demikian, terdapat beberapa komentar dan saran dari validator untuk dilakukan revisi kecil agar produk yang dikembangkan yaitu Lembar Kegiatan Mahasiswa berbasis eksperimen menjadi produk yang lebih baik. Setelah diperbaiki berdasarkan komentar dan saran dari validator, selanjutnya diperlukan uji coba produk oleh mahasiswa untuk melihat kelayakan bahan ajar. Hal ini sesuai dengan Nugraha, dkk (2013) bahwa bahan ajar yang telah memenuhi kategori kevalidan dapat dilanjutkan menuju tahap penelitian berikutnya.

\section{Analisis Kelayakan}

Pada tahap ini dilakukan uji coba I terhadap produk yang dikembangkan yaitu Lembar Kegiatan Mahasiswa berbasis eksperimen yang telah divalidasi. Uji coba I dilakukan kepada 6 mahasiswa Program Studi Pendidikan Kimia yang mewakili populasi mahasiswa berdasarkan tingkat kemampuan tinggi, sedang dan rendah. Penentuan tingkat kemampuan tersebut berdasarkan Indeks Prestasi Kumulatif (IPK) mahasiswa. Pada tahap ini masing-masing mahasiswa diberikan Lembar Kegiatan Mahasiswa berbasis eksperimen untuk dipelajari. Peneliti juga memberikan angket respon untuk diisi mahasiswa dalam mengukur tingkat kelayakan tampilan produk.

Jumlah persentase yang diperoleh dari hasil angket respon mahasiswa pada tahap uji coba I sebesar 90,98\%. Sehingga berdasarkan tabel kategori kelayakan, Lembar Kegiatan Mahasiswa berbasis eksperimen termasuk ke dalam kategori sangat layak menjadi bahan ajar mata kuliah Kimia Lingkungan, khususnya pada materi Pencemaran Lingkungan. Pada tahap ini juga diperoleh komentar kelebihan, kekurangan dan saran terhadap produk (Draft I) yang digunakan untuk perbaikan dan penyempurnaan produk (Draft II). Hasil perbaikan pada tahap uji coba I diperoleh Draft II yang akan diujikan pada tahap uji coba II di tahap selanjutnya.

Pada tahap selanjutnya, peneliti melakukan uji coba pada Draft II untuk menguji kelayakan produk yang telah diperbaiki. Draft II diujicobakan dengan melibatkan 15 mahasiswa Program Studi Pendidikan Kimia. Peneliti memberikan Draft II dan lembar angket kepada masing-masing mahasiswa. Adapun rekapitulasi hasil analisis angket respon mahasiswa dapat dilihat pada Tabel 4.

Tabel 4. Rekapitulasi Hasil Angket Respon Mahasiswa

\begin{tabular}{|c|c|c|}
\hline No & Uji Coba & Nilai Respon \\
\hline 1 & I & $90,98 \%$ \\
\hline 2 & II & $89,16 \%$ \\
\hline
\end{tabular}
penurunan nilai respon mahasiswa setelah dua kali uji coba produk sebesar 1,82. Hal ini dimungkinkan karena adanya penambahan jumlah sampel mahasiswa dengan perbedaan karakteristik penilaian. Namun demikian, hasil analisis data angket respon mahasiswa terhadap Draft II diperoleh sebesar 89,16\%. Artinya, Lembar Kegiatan Mahasiswa berbasis eksperimen memenuhi kategori kelayakan dan dinyatakan sangat layak untuk dijadikan sebagai bahan ajar yang dapat membantu mahasiswa mempelajari materi Pencemaran Lingkungan dengan kegiatankegiatan eksperimen sederhana. Hal ini sesuai dengan penelitian Fitriyati, dkk (2015) yang mengembangkan bahan ajar dengan memadukan teori dengan kegiatan eksperimen, sehingga mahasiswa dapat memahami secara konkrit penerapan konsep yang dipelajari. Lembar Kegiatan Mahasiswa berbasis eksperimen yang telah dikembangkan ini menyajikan aplikasi teori Pencemaran Lingkungan dengan kegiatan eksperimen, sehingga dapat dijadikan rujukan 
dalam proses pembelajaran mata kuliah Kimia Lingkungan.

\section{Kesimpulan}

Lembar Kegiatan Mahasiswa berbasis eksperimen yang dikembangkan pada penelitian ini telah dapat digunakan sebagai bahan ajar untuk mata kuliah Kimia Lingkungan pada materi Pencemaran Lingkungan, karena telah memenuhi kategori kevalidan dan kelayakan seperti: 1) Hasil analisis kevalidan Lembar Kegiatan Mahasiswa berbasis eksperimen berdasarkan penilaian dari tiga validator menunjukkan nilai persentase sebesar 93,52\% (sangat valid). 2) Hasil analisis kelayakan Lembar Kegiatan Mahasiswa berbasis eksperimen berdasarkan angket respon mahasiswa pada uji coba I diperoleh sebesar 90,98\% (sangat layak) sedangkan uji coba II diperoleh sebesar $89,16 \%$ (sangat layak).

\section{Daftar Pustaka}

Akbar, S. 2013. Instrumen Perangkat Pembelajaran. Bandung: PT Remaja Rosdakarya.

Arikunto, S. 2006. Prosedur Penelitian Suatu Pendekatan Praktik. Jakarta: Asdimahasatya.

Eurika. N. 2013. Pengembangan Bahan Ajar Materi Populasi Hewan. Didaktika. 11 (2).

Fitriyati, U., Mufti, N \& Lestari, U. 2015. Pengembangan Modul Berbasis Riset pada Mata Kuliah Bioteknologi. Jurnal Pendidikan Sains. 3 (3).

Juniati, D \& Budayasa, I.K. 2017. Pengembangan Bahan Ajar Geometri Fraktal Berbasis Eksperimen Untuk Meningkatkan Kompetensi Mahasiswa. Cakrawala Pendidikan. 36 (1).

Mahardika, A.I \& Mastuang. 2016. Pengembangan LKM dan Materi Ajar Topik Teori Kinetik Gas Mata Kuliah Temodinamika Untuk Melatihkan Penalaran Proporsional. Jurnal Sains dan Pendidikan Fisika. 12 (2).

Mulyasa. 2006. Kurikulum Tingkat Satuan Pendidikan. Bandung: Rosdakarya.

Mulyatiningsih, E. 2014. Metode Penelitian Terapan Bidang Pendidikan. Bandung: Alfabeta.

Nugraha, D.A., Achmad, B \& Supartono. 2013. Media Reaksi Redoks Bervisi SETS
Berorientasi Konstruktivistik. Journal of Innovative Science Education. 2 (1).

Palar, H. 2008. Pencemaran dan Toksikologi Logam Berat. Jakarta: Rineka Cipta.

Riduwan. (2009). Metode dan Teknik Menyusun Tesis. Bandung: Alfabeta.

Situmorang, M. 2012. Kimia Lingkungan. Medan: Penerbit Fakultas Matematika dan Ilmu Pengetahuan Alam Universitas Negeri Medan.

Thiagarajan, S \& Semmel, D. S \& Semmel, M. I. 1974. Instructional Development for Training Teacher of Expentional Children. Bloomington: Indiana University.

Trianto. 2010. Model Pembelajaran Terpadu. Jakarta: Prestasi Pustaka. 